\title{
Revisiting estimates of municipal solid waste generation per capita and their reliability
}

\author{
Kosuke Kawai · Tomohiro Tasaki
}

Received: 4 August 2014/ Accepted: 17 January 2015/Published online: 5 February 2015

(C) The Author(s) 2015. This article is published with open access at Springerlink.com

\begin{abstract}
Per capita municipal solid waste (MSW) generation, a core indicator of environmental pressure, is a useful measure for evaluating the intensity of waste generation over time and comparing the intensities among cities or countries. We provide an overview of global data on MSW generation per capita at the national and local levels. Although the legal definition of MSW varies from country to country, we conceptualize MSW simply as the waste managed by or for municipalities as a public service. We note the current challenges in estimating MSW generation per capita in developing countries, including a lack of equipment (e.g., weighbridges), lower rates of MSW collection efficiency, and rural-urban migration, all of which may have negative effects on data reliability. Incomplete data compilation systems at the national level also result in lower reliability and reduce the comparability of national data. We suggest technical solutions for estimating MSW generation per capita at the local and national levels to improve reliability and comparability of data.
\end{abstract}

Keywords Municipal solid waste - Waste generation · Reliability · Definition · Comparability

\section{Introduction}

Currently, 1.3 billion metric tons of municipal solid waste (MSW) are generated annually in the world, and this amount is expected to rise to about 2.2 billion tons by 2025 [1],

K. Kawai $(\bowtie) \cdot$ T. Tasaki

Center for Material Cycles and Waste Management Research,

National Institute for Environmental Studies, 16-2 Onogawa,

Tsukuba, Ibaraki 305-8506, Japan

e-mail: kawai.kosuke@nies.go.jp although MSW generation in Organisation for Economic Co-operation and Development (OECD) member countries has been decreasing [2]. MSW generation is influenced by economic conditions, living standards, urbanization [3, 4], and population [5]. Dramatic increases in population in urban areas are typical phenomena in Africa and Asia [6], and the amount of MSW generated dramatically increases as a consequence. Historical data compilation of MSW generation per capita, a core indicator of environmental pressure $[7,8]$ to evaluate the intensity of MSW generation, can contribute to better MSW management planning. Data on MSW generation per capita are also useful for comparisons of MSW intensities among countries and cities. In spite of the usefulness of this measure, international comparability is not fully assured because of inconsistent national definitions of MSW and unreliable data on MSW generation per capita. Comprehensive articles reviewing MSW definitions have yet to be published, although some researchers have specifically addressed the definition of MSW in their studies [9-12].

In this article, we provide an overview of global data on MSW generation per capita at the national and local levels. Because of our concern that the disparity of MSW definitions in the world would lead to reduced comparability, we review various definitions of MSW and accordingly explain about the MSW stream. With a focus on developing countries, we clarify existing local problems with data reliability in terms of MSW generation and the population with MSW collection service because uncertainties seriously affect the reliability and comparability of MSW generation per capita data. We raise the issue of compiling local data for estimation of nationwide MSW generation per capita. We suggest technical solutions for estimating MSW generation per capita at the local and national levels to improve reliability and comparability of data. 


\section{Overview of global data on MSW generation per capita}

Calculating MSW generation per capita enables data on MSW generation to be normalized and eliminates the effects of changes in population [13]. Per capita data are widely used to compare the intensity of MSW generation among different places [14-20].

MSW generation per capita at the national level

Figures 1, 2, 3, 4, 5, 6, and 7 show the latest available data on MSW generation per capita of 157 countries by region [1, 21-39]. Data for the 34 OECD member countries are from the OECD's iLibrary database, which compiles annual data on MSW generation per capita for all member countries. Data for European Union (EU) member countries other than OECD member countries (Romania, Latvia, Serbia, Croatia, Bulgaria, Lithuania, and Cyprus) are from Eurostat statistics. Data for some other countries were published by international organizations, and some were investigated by individual researchers and consultants. MSW generation per

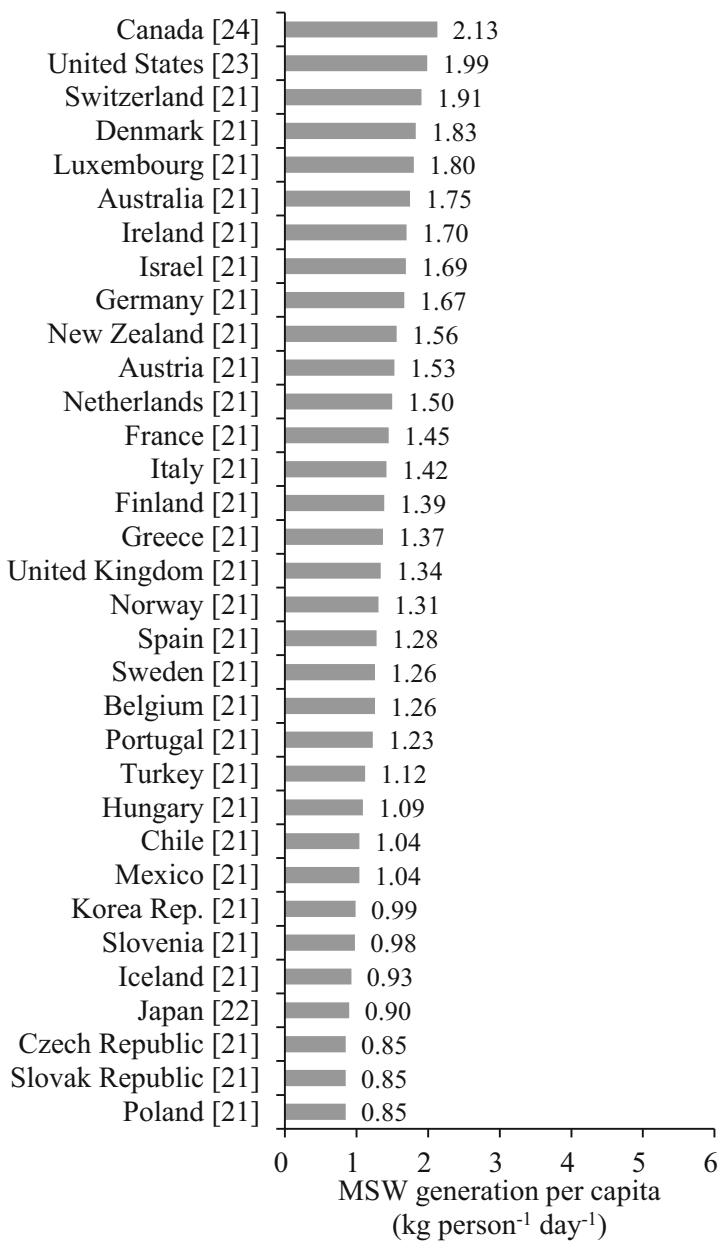

Fig. 1 MSW generation per capita in OECD member countries capita ranged from $0.09 \mathrm{~kg} \mathrm{day}^{-1}$ in Ghana to $5.50 \mathrm{~kg} \mathrm{day}^{-1}$ in Antigua and Barbuda; the median was $0.94 \mathrm{~kg} \mathrm{day}^{-1}$. Data from developing countries were generally difficult to obtain and open data sources are limited.

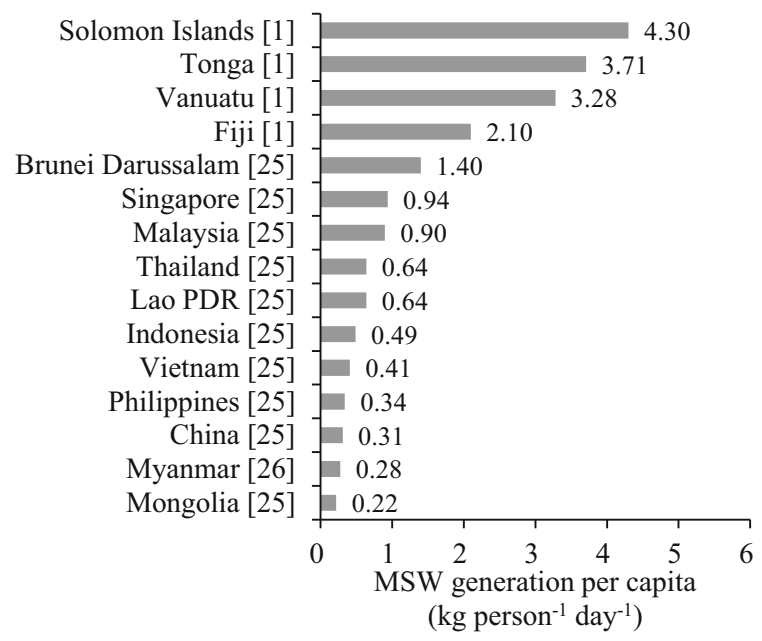

Fig. 2 MSW generation per capita in East Asia and the Pacific islands

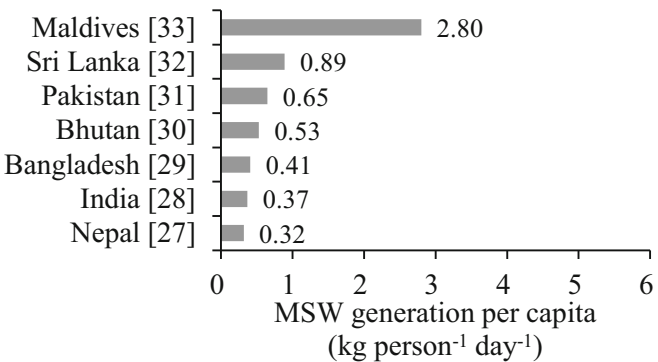

Fig. 3 MSW generation per capita in South Asia

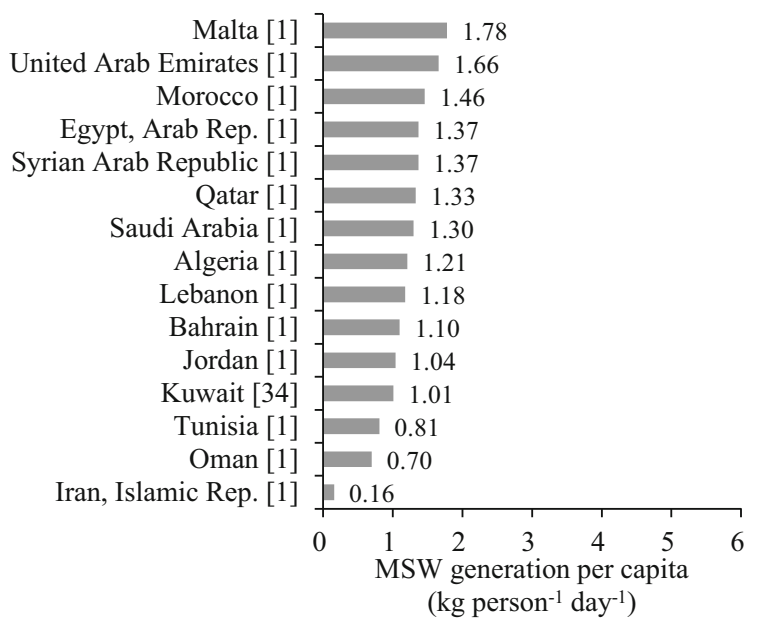

Fig. 4 MSW generation per capita in the Middle East and North Africa 


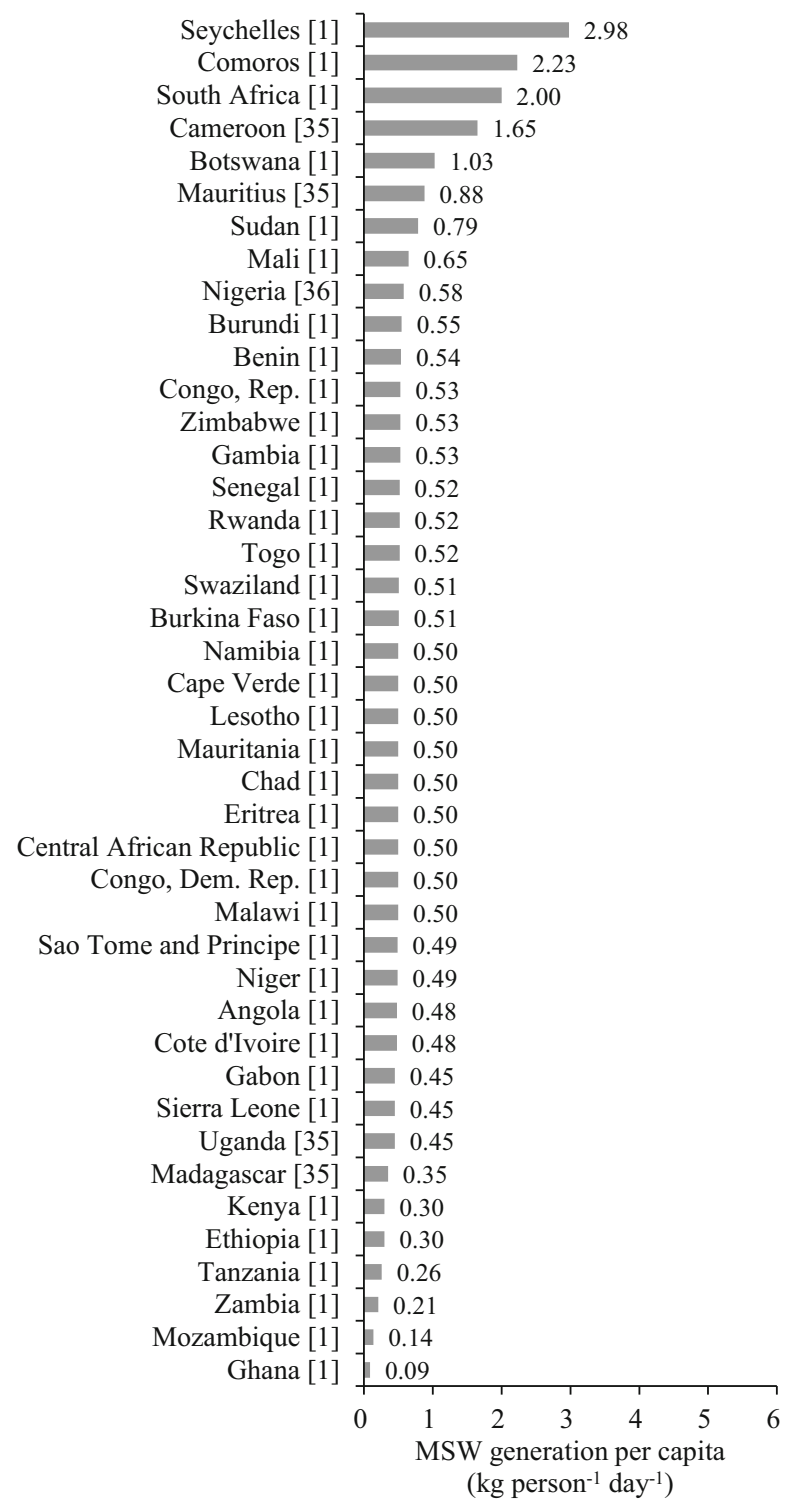

Fig. 5 MSW generation per capita in Sub-Saharan Africa

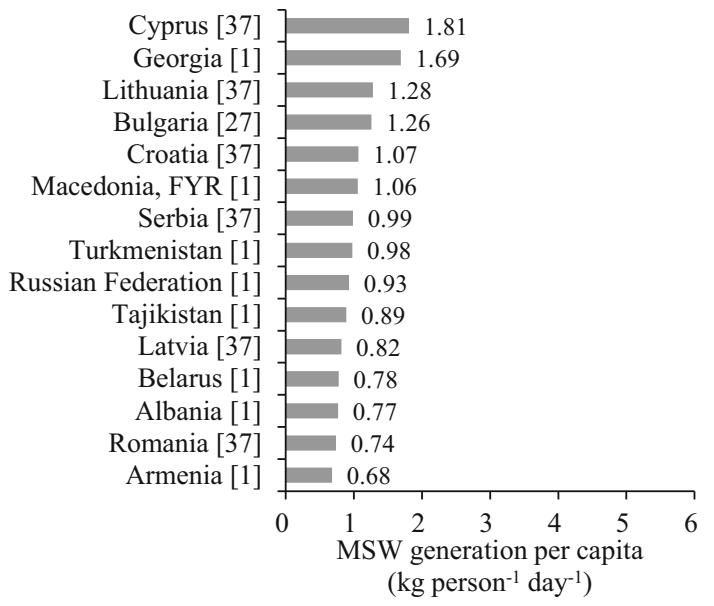

Fig. 6 MSW generation per capita in Eastern Europe and Central Asia

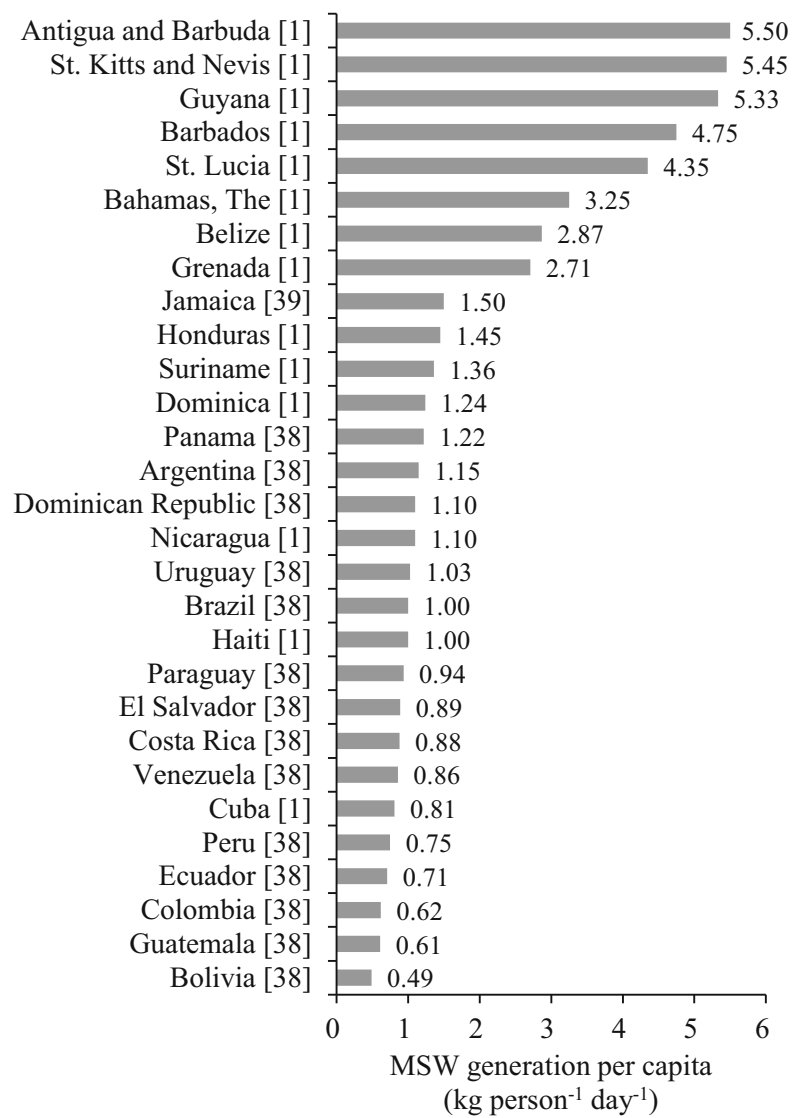

Fig. 7 MSW generation per capita in Latin America and the Caribbean

As a result, the reliability and timeliness of data cannot be guaranteed in developing countries with the exception of countries where ad hoc international support projects have been conducted, such as in Nepal [27].

In international comparisons of national MSW generation per capita, corresponding socio-economic indicators are often cited to illustrate that larger values of MSW per capita are generated in places with higher socio-economic indicators. Gross domestic product (GDP) per capita is a typical economic index correlated with MSW generation per capita [40-42], although the correlation is not strong. Gross national income (GNI), the sum of a nation's GDP plus net income received from overseas, is also used in place of GDP [43]. The Human Development Index (HDI), which measures the average achievements in a country with regard to its residents having a long and healthy life, access to education, and a decent standard of living, is applied as well [44]. These three indicators are correlated with one another. Worldwide, in 2012, a significant positive correlation $(r=0.985, p<0.001)$ was observed between GDP per capita [45] and GNI per capita [46], and HDI [47] was correlated with logarithmically transformed GDP per capita $(r=0.928, p<0.001)$ and GNI per capita $(r=0.934, p<0.001)$. Figure 8 illustrates the relationship 
between MSW generation per capita (Figs. 1, 2, 3, 4, 5, 6, 7) and GDP per capita in 2012 or the latest available year [45] for 156 countries. Myanmar is not included because GDP per capita data were not available. MSW generation per capita in countries with a per capita GDP of less than US $\$ 20,000$ fluctuated more widely than those with a higher per capita GDP. The standard deviations of MSW generation per capita in the lower and higher income groups were 1.09 and 0.44 , respectively.

As an economy matures and environmentally friendly policies are enforced, MSW generation per capita does not always increase in line with economic growth. For example, after 20 years of rapid economic growth through 1997, the government of Taiwan enforced aggressive MSW

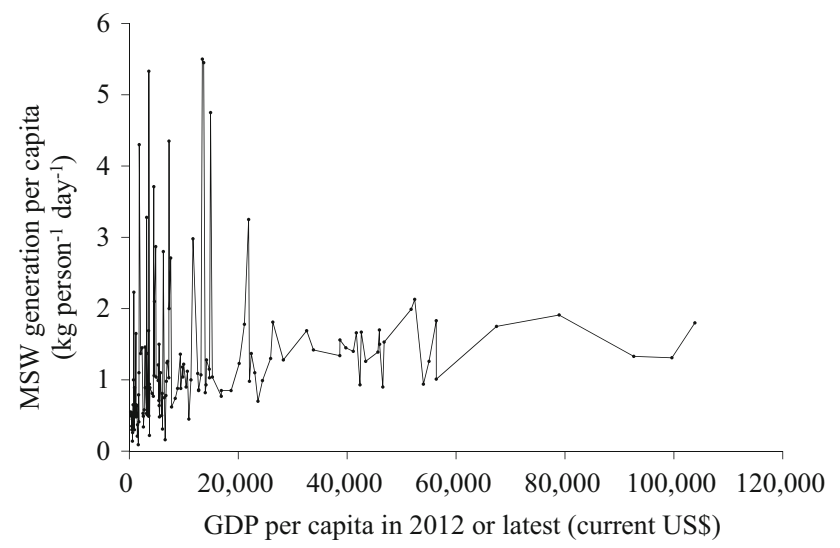

Fig. 8 MSW generation and GDP (both per capita) of 156 countries $[1,21-39,45]$

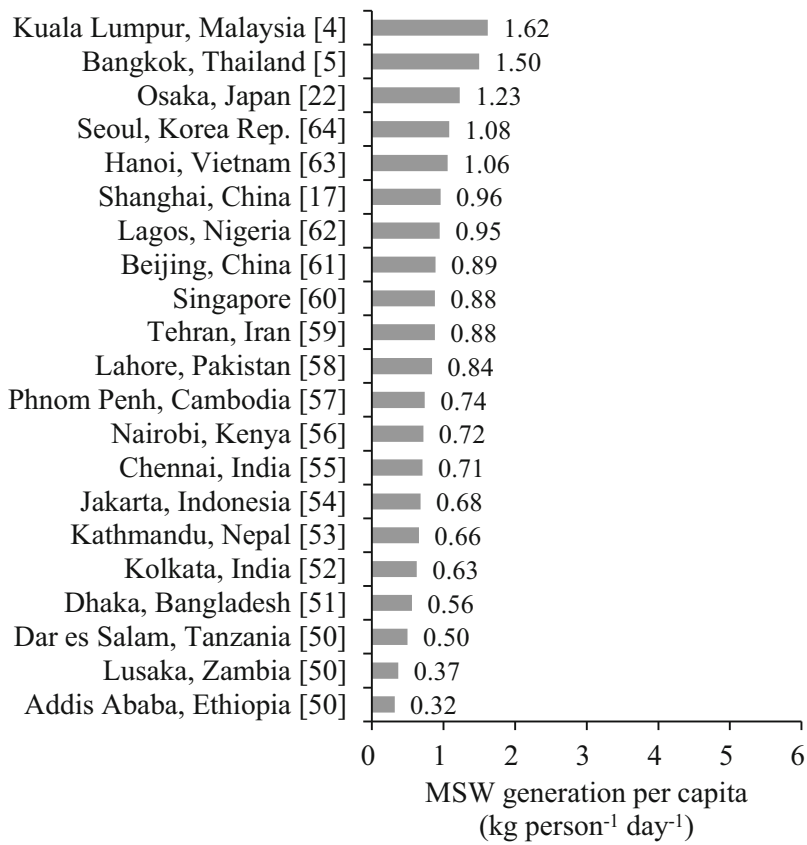

Fig. 9 MSW generation per capita of 20 major municipalities in Asia and Africa management practices [48], which contributed to a large reduction in the per capita MSW generation from $1.14 \mathrm{~kg} \mathrm{day}^{-1}$ in 1997 to $0.81 \mathrm{~kg} \mathrm{day}^{-1}$ in 2002 [49], even though the economy continued to grow.

MSW generation per capita at the local level

Figure 9 shows MSW generation per capita for 20 major municipalities in Asia and Africa [4, 5, 17, 22, 50-64]. Each municipal value exceeds the corresponding national value for MSW generation per capita (Figs. 1, 2, 3, 4, 5, 6, 7). Per capita MSW generation in some large Asian cities, especially Kuala Lumpur (Malaysia) and Bangkok (Thailand), has already reached the level of OECD member countries.

MSW generation per capita varies among municipalities within countries. Urbanization has a positive effect on increasing MSW generation per capita, especially in developing countries, where disparities in economic activities and living standards between rural and urban areas are large. MSW per capita in urban municipalities has been reported to be more than that in rural municipalities in developing countries. For example, in Vietnam, MSW generation per capita was reported to be $0.70 \mathrm{~kg} \mathrm{day}^{-1}$ in urban areas and $0.30 \mathrm{~kg} \mathrm{day}^{-1}$ in rural areas [65]. In developed countries, MSW generation per capita generally does not vary as much between rural and urban municipalities. According to Japanese statistics [22], however, the standard deviation of MSW generation per capita of municipalities with a lower population density (rural municipalities) was larger than that of more densely populated areas (urban municipalities); that is, per capita MSW generation in rural areas was more widely ranging (Fig. 10).

Tourism may also have an impact on MSW generation [66, 67]. For example, Pattaya (Thailand), a beach resort city approximately $160 \mathrm{~km}$ from Bangkok, has a much higher MSW generation per capita $\left(1.00 \mathrm{~kg} \mathrm{day}^{-1}\right)$ [5] than the national average $\left(0.64 \mathrm{~kg} \mathrm{day}^{-1}\right)$.

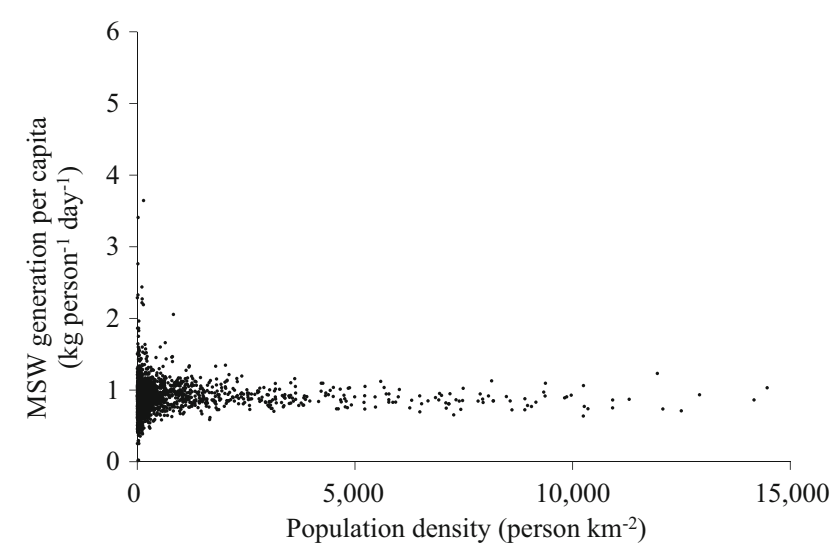

Fig. 10 Distribution of MSW generation per capita of 1715 municipalities in Japan in FY2012 


\section{Definitions of MSW}

Generally municipalities or local governments have the responsibility of managing MSW, with a few exceptions such as in Malaysia, which shifted the responsibility for MSW to the federal government [68]. The existence of different definitions of MSW [69] makes it confusing to interpret and compare estimates of MSW generation in various countries.

Waste is generated in all sorts of ways and its composition and volume largely depend on consumption patterns and on industrial and economic structures [70]. Although the legal definition of waste differs among countries, wastes are substances or objects that are disposed of, intended to be disposed of, or required to be disposed of by the provisions of national law according to Article 2 of the Basel Convention on the control of transboundary movements of hazardous wastes and their disposal. Waste is similarly defined in EU Directive 2008/98/EC as any substance or object that the holder discards, intends to discard, or is required to discard [71]. In another sense, waste refers to material that is discarded without being resold to other persons or companies, and it generates collection, transportation, and disposal costs. In Japan, after careful and comprehensive evaluations, waste is defined on the basis of the following five categories-(a) item meets required quality for use, (b) supply and demand, (c) product market, (d) transaction value, and (e) intention of owner to sell. Under this type of definition, recyclables (salables) are not considered to be waste.

In general, the sources (generators) of and the properties of waste defined as MSW determine the application range of MSW [72], but Buenrostro et al. [11] conceptualized the territorial limits of a municipality as the boundary of MSW. According to the OECD [2], "Municipal waste is waste collected by or on behalf of municipalities. It includes household waste originating from households (i.e. waste generated by the domestic activity of households) and similar waste from small commercial activities, office buildings, institutions such as schools and government buildings, and small businesses that treat or dispose of waste at the same facilities used for municipally collected waste." However, the definition reported by the World Bank includes industrial waste and construction and demolition waste in MSW streams [1]. Rodic et al. [12] reported that several municipalities such as Adelaide in Australia and Belo Horizonte in Brazil also include construction and demolition waste as MSW. The Canadian government also defines construction and demolition waste as a component of MSW [73]. The US Environmental Protection Agency definition does not include construction and demolition debris, biosolids (sewage sludges), industrial process wastes, junked cars and trucks, or combustion ash, but US states have different definitions of MSW [74].

For the purposes of national annual reporting of MSW from EU countries, the Eurostat/OECD defines MSW to include household and similar wastes, placing emphasis on inclusion by listing all the possible sources and material types [75]. Another EU commission decision defines municipal waste to include household and similar wastes, but to exclude production waste and waste from agriculture and forestry [76]. Chapter 20 in the European List of Wastes defines municipal waste as household waste and similar commercial, industrial, and institutional wastes, including street cleaning residues, septic tank sludge, and waste from sewage cleaning [77]. Most EU member countries use this List of Wastes as a guide when compiling statistics, even though they are not obligated to do so [78]. The List of Wastes excludes packaging waste from municipal waste to emphasize producer responsibility for packaging waste, and this exclusion may cause EU member countries to have different definitions of MSW. For example, packaging waste destined for recycling is included as MSW in the United Kingdom [79] and Denmark [80], but it is not always reported as MSW in Germany [81] and France [82]. The variance is a result of different policies on producer responsibility among EU member countries.

The definitions also vary across Southeast Asia. The Philippine definition of municipal waste as defined by Republic Act No. 9003 refers to wastes produced from activities within local governmental units, including domestic, commercial, institutional, and industrial wastes as well as street litter. Malaysia, Vietnam, and Cambodia, on the other hand, have no legal definition of MSW [25]. Waste managed by or for municipalities is often translated as MSW in English regardless of the official wording in the native language. Countries without a legal definition of MSW in relevant laws do not use the terms "municipal solid waste" or "MSW" in their native languages, and the waste categories can often be translated into English as "ordinary solid waste," "urban solid waste," or similar terms. In an exact translation, the Japanese government considers the MSW category as "general waste," and general waste is defined simply as waste other than industrial waste, all of which shall be managed by or for municipalities according to the Waste Management and Public Cleansing Act.

Waste can be categorized as hazardous or non-hazardous. Non-hazardous wastes generated from relatively small-scale sources and public spaces tend to be thought of as MSW. Non-hazardous wastes consist of kitchen waste, garden waste, paper and cardboard, textiles, plastics, metals, and similar materials [83] that are generated from the activities of daily life. Electrical and electronic waste (e- 
waste), batteries, fluorescent lamps, and spray cans disposed of by households are also usually regarded as MSW, even though they may contain hazardous materials [84, 85]. Infectious wastes such as needles and blood generated from hospitals and clinics are designated as specially controlled wastes and are not included as MSW in Japan [86]. However, bandages and surgical cotton containing blood generated from the same types of places are managed as MSW. Waste materials originating from home health and medical care services are included in MSW [87].

Globally, it appears that household waste is the main component of MSW, even though it may contain some amount of hazardous materials. Other than household waste, each municipality determines the sources and types of waste to be covered by MSW management depending on political, historical, social, and economic factors. Some municipalities may also regard waste from industry as MSW. MSW can be simply conceptualized as the waste managed by or for municipalities as a public service through a public works budget. MSW is often managed by private companies on behalf of local governments through private finance initiatives and public private partnerships $[88,89]$. When calculating MSW generation per capita, the reporters of the data should clearly note and declare the sources and types of waste included as MSW to verify the comparability of data.

\section{Identification of the MSW stream from the source of waste generation}

The MSW stream should be clearly identified and distinguished from other waste streams so that data on MSW generation can be appropriately captured. Here, the MSW stream refers to the stream shown in Fig. 11a. The waste in stream (b), such as industrial waste in Japan, is not managed by municipalities because they do not recognize this type of waste to be covered by a public service. It is, therefore, not regarded as MSW because the waste is disposed of at the generators' own expense.

The MSW stream excludes other two streams. The first is recyclables collected by anyone other than municipalities, such as the private sector and the informal sector (Fig. 11c). This stream emerges in isolation from MSW and is mainly driven by economic incentives. This type of recycling is often observed in developing countries [9092], where junk buyers in cities and waste pickers at dumping sites recover recyclables to earn a living [93, 94]. The informal sector accordingly contributes to a reduction of MSW generation and drives the recycling process in developing countries [95]. Communities and schools can also be key actors for recycling. In Thailand, waste banks in the community and at schools play an important role as places where pupils and residents can sell recyclable materials [96]. Wong Panit, a Thai private trading company of recyclables, initially partnered with the city of Phitsanulok in Thailand to set up waste banks and promote community-based recycling activities, resulting in a drastic decrease in the amount of MSW generated [97] and reaching the activities to reduce MSW in Bangkok [5].

The other waste stream excluded is that which is selfdisposed of at the source (Fig. 11d). This type of waste stream is commonly seen in regions where MSW collection service is unavailable [57]. Burning, composting, burial, and disposal into water bodies are examples of self-disposal regardless of whether they are done properly or improperly [98]. Composting at the household level in Surabaya, Indonesia [99], is a good example of appropriate self-disposal.

Data on the amount of MSW disposal do not necessarily correspond to those of MSW generation, especially in developing countries [100]. Many municipalities throughout the world tend to report the amount of MSW disposed of as well as that recycled as the amount of MSW generated because the data are recorded at disposal and recycling sites equipped with weighbridges. In fact, some of the
Fig. 11 Conceptual diagram of waste streams generated from the source of waste generation

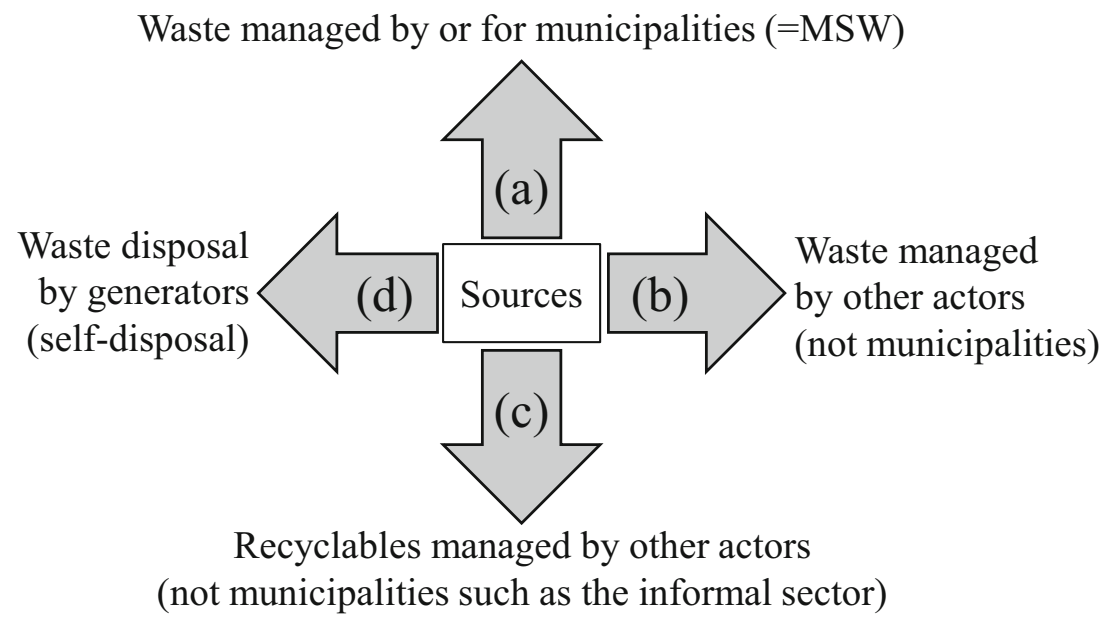


recyclables are informally recovered from the MSW stream (Fig. 11a) and flow into recyclable stream (Fig. 11c) during each process in developing countries-by waste pickers during the discharge process, by MSW collection workers during the collection process, by MSW transportation workers during the transportation process, and by waste pickers during the disposal process [101, 102].

\section{Reliability of data related to MSW generation per capita}

Municipal solid waste generation per capita is simply calculated as the amount of MSW generated divided by the population with MSW collection service. Uncertainty in either value can negatively affect the reliability and comparability of the data. Here the potential causes of the uncertainties, especially in developing countries, are discussed and feasible solutions to improve the uncertainties are suggested. Non-MSW waste streams are not accounted for and the amount of MSW disposal is considered to be equal to that of MSW generation in the following discussion, even though that may not necessarily be the case in developing countries.

\section{Amount of MSW generation at the local level}

The amount of MSW generated annually is fundamental information and should be reliable because municipalities usually prepare annual budgets for MSW management based on annual MSW generation. The use of weighbridges increases the reliability of data on MSW generation [103], but smaller municipalities often cannot afford weighbridges because of budget constraints. This disadvantage is evident in many developing countries, and many smaller municipalities have to estimate the annual MSW generation based on available information. A common way to estimate the amount of MSW generated based on the available information on waste transportation by trucks is shown in Eq. (1):

$W=c \times v \times d \times t \times l \times 365$,

where $W$ is annual MSW generation amount (tons year ${ }^{-1}$ ), $c$ is the average capacity of a waste-hauling truck $\left(\mathrm{m}^{3}\right.$ truck $\left.^{-1}\right), v$ is the average loading volume ratio of a truck, $d$ is the average density of MSW loaded on truck (tons $\mathrm{m}^{-3}$ ), $t$ is the average number of trips per truck (frequency of trips day ${ }^{-1}$ ), and $l$ is the average number of operating trucks (number of trucks day ${ }^{-1}$ ). Although MSW generation estimates without weighbridge data are less reliable because of uncertainties related to the parameters, the data can be improved using parameters on each hauling truck, as in Eq. (2):
$W=\sum_{j=1}^{365} \sum_{i=1}^{m}\left(c_{i} \times v_{i} \times d_{i} \times t_{i j}\right)$,

where $m$ is total number of trucks, $c_{i}$ is the capacity of truck $i\left(\mathrm{~m}^{3}\right.$ truck $\left.^{-1}\right), v_{i}$ is the loading volume ratio of truck $i, d_{i}$ is the density of MSW loaded on truck $i$ (tons $\mathrm{m}^{-3}$ ), and $t_{i j}$ is the number of trips by truck $i$ on day $j$ (frequency of trips day ${ }^{-1}$ ).

Many municipalities entrust collection and transportation of MSW and operations at transfer stations, recycling facilities, and landfill sites to private companies or others and pay a commission in proportion to the amount of MSW collected or processed. Larger municipalities often install weighbridges and assign municipal officers to closely monitor the site operators and prevent them from reporting intentionally inflated amounts of MSW. The annual amount is simply the sum of all recorded MSW weights at a weighbridge during a year, as shown in Eq. (3):

$W=\sum_{j=1}^{365} \sum_{i=1}^{m} w_{i j}$

where $w_{i j}$ is the recorded weight of MSW loaded on truck $i$ on day $j$ (tons).

Limited MSW collection service at the local level

Statistical demographics should not be used to calculate MSW generation per capita; rather, population with MSW collection service should be used. Data on population with MSW collection service may be uncertain in developing countries because of issues related to collection efficiency and rural-urban migration. These issues can result in both underestimations and overestimations of MSW generation per capita.

UN-HABITAT [104] gave an overview of the solid waste systems in 20 cities around the world, including the collection efficiency (percentage coverage) (Fig. 12). Regions with low-income countries tended to have low collection efficiencies. The collection efficiency rate varies within nations in developing countries, and major cities achieve a higher collection rate, whereas the rates are much lower in smaller cities [105]. For example, in South Africa, more than $90 \%$ of households in urban Gauteng and Western Cape were covered with MSW collection services, but the coverage in more rural areas such as Eastern Cape, Mpumalanga, and Limpopo was less than $50 \%$ [106]. MSW management policies in developing countries generally first focus on the timely removal of wastes from densely populated areas to maintain hygiene and health [107]. Thinly populated areas, where empty spaces are available for waste disposal, are not always covered by MSW collection service because of limited municipal 
Fig. 12 Collection efficiency of MSW in 20 municipalities [104]

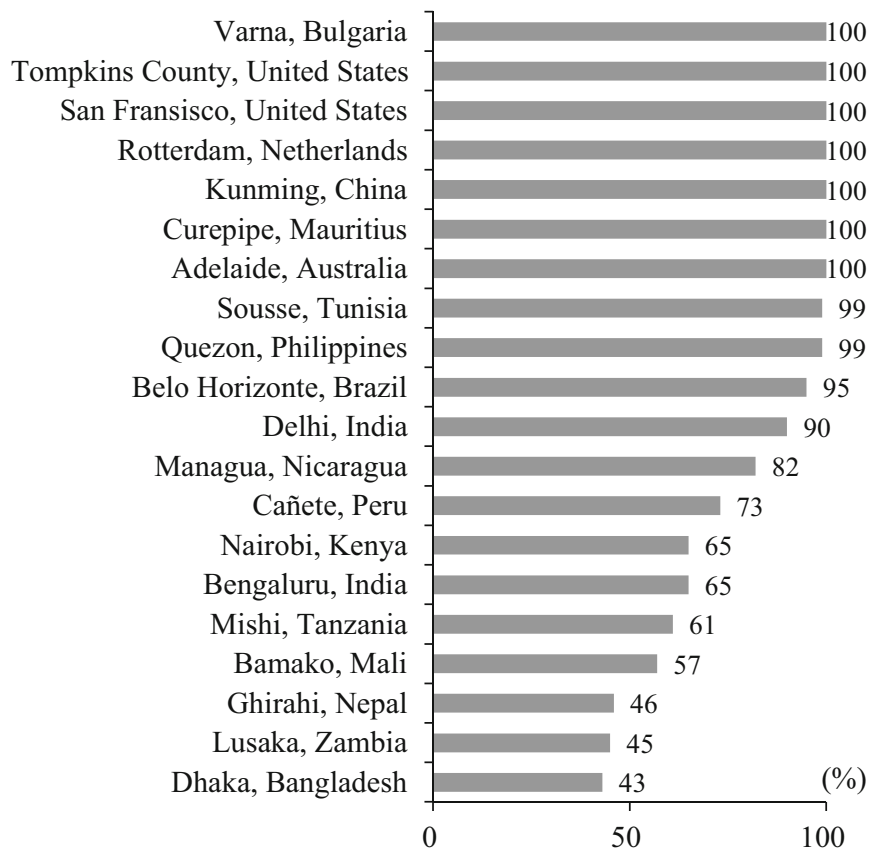

expanded as a result. That is, residential areas in suburbs, which are covered by MSW collection service, are expanding rapidly, and the amount of MSW generated in these areas increases dramatically. For example, the amount of MSW collected from suburban districts in Hanoi, Vietnam, rapidly increased from 2000 to 2011, as the population grew rapidly and the municipality expanded the coverage of MSW collection service in the expanding suburban areas (Fig. 13) [114]. On the other hand, the amounts of MSW collected from core urban districts (Ba Dinh, Hoan Kiem, Dong Da, and Hai Ba Trung districts) were relatively stable because the population was also relatively stable. Economically vital municipalities in developing countries should pay attention to MSW generation as well as population with MSW collection service in newly urbanized areas when estimating MSW generation per capita.

Data compilation system at the national level

As shown in Fig. 8, MSW generation per capita in the group of countries with a GDP per capita of less than US $\$ 20,000$ fluctuated more widely than that of the higher income group. This trend indicates that most developing countries are incapable of compiling the necessary data to accurately calculate the nationwide per capita data. National governments need to compile data on MSW generation and population with collection service from local governments for the precise calculation of nationwide data, as shown in Eq. (4): 


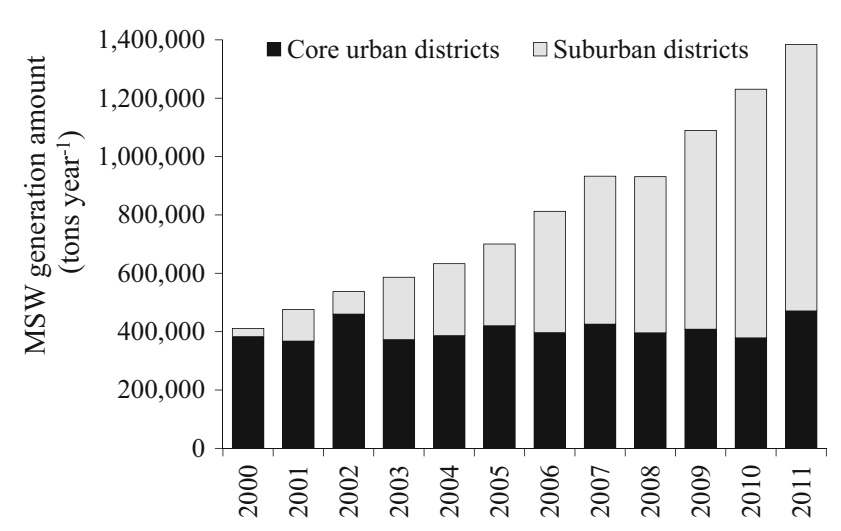

Fig. 13 Amount of MSW generated in Hanoi, Vietnam, 2000-2011

$W_{\mathrm{c}}=\frac{\sum_{k=1}^{n} W_{k}}{\sum_{k=1}^{n} P_{k}} \times \frac{10^{3}}{365}$,

where $W_{\mathrm{c}}$ is nationwide MSW generation per capita $\left(\mathrm{kg} \mathrm{day}^{-1}\right.$ ), $n$ is the number of municipalities for which data are compiled, $W_{k}$ is annual MSW generation amount in municipality $k$ (tons year ${ }^{-1}$ ), and $P_{k}$ is population with MSW collection service in municipality $k$ (persons). The number of municipalities $(n)$ should ideally be commensurated with the total number of municipalities in the nation. Many developing countries, however, have not established a system for compiling such data. The average value of available local per capita data may be regarded as the nationwide value in some developing countries, as shown in Eq. (5):

$W_{\mathrm{c}}=\frac{1}{n} \sum_{k=1}^{n} \frac{W_{k}}{P_{k}} \times \frac{10^{3}}{365}$.

With enough data, the values of nationwide MSW generation per capita estimated by Eqs. (4) and (5) would approximate each other; for example, MSW generation per capita in Japan estimated by Eqs. (4) and (5) were 0.9006 and $0.9032 \mathrm{~kg}$, respectively, based on data from FY2012 compiled from all municipalities $(n=1715)$. However, if fewer data on MSW generation per capita can be collected from municipalities, the reliability of average data estimated by Eq. (5) will be reduced, and the estimates will not necessarily be close to those generated by Eq. (4). National governments should compile data on MSW generation and population with MSW collection service from as many municipalities as possible in developing countries to improve the reliability of data on MSW generation per capita.

One reason that data on MSW management are not exhaustively compiled in developing countries is that local governments do not have financially close connections with national governments. Conversely, the Japanese government established a data compilation system. The
Ministry of the Environment, which holds jurisdiction over waste management in Japan, requires all municipalities to report data on local MSW management, including MSW generation and population with MSW collection service, annually to collect basic information to improve MSW management in Japan. From a practical standpoint, the municipalities are motivated to collect reliable data on local MSW management and prepare detailed plans for constructing new waste treatment facilities because it is a condition of receiving a subsidy from the Ministry of the Environment.

A lack of education and training of local staff in developing countries may lead to misreporting of local MSW data to national governments. Municipal staff may carelessly or erroneously handle data on MSW generation and population with MSW collection service [103]. The national governments should, therefore, verify the data from municipalities. Estimating MSW generation per capita by dividing the amount of MSW generation by the population with MSW collection service is a simple but effective way to identify obvious errors in the reported data [115]. About $50 \%$ of the 157 countries shown in Figs. 1, 2, $3,4,5,6,7$ had a MSW generation per capita of $0.53-1.39 \mathrm{~kg}$, so values very far outside of that range should be reevaluated. For example, MSW generation per capita values of 0.10 or $10 \mathrm{~kg}$ should be considered suspect because simple calculation or data entry errors may have occurred in estimating the values.

\section{Conclusions}

Differences in the amount of MSW generated per capita should reflect each nation's or municipal area's different state of socio-economic growth and the nature of environmental policies. Other factors, however, also contribute to poor comparability among different areas. These include differences in the definition of MSW and uncertainties in the data used to calculate MSW generation per capita. The definition of MSW also varies from country to country because each country and municipality define MSW based on its own political, social, and economic framework. That said MSW can be simply conceptualized as the waste managed by or for municipalities as a public service. A lack of equipment (e.g., weighbridges), lower rates of MSW collection efficiency, rural-urban migration, and incomplete data compilation systems at the national level all affect the reliability of data used to estimate MSW generation per capita in developing countries. Although uncertainties can never be completely eliminated, data on population with MSW collection service as well as MSW generation should be estimated as accurately as possible. Otherwise, local and national governments will estimate 
MSW generation per capita improperly, which hampers the comparability of estimates both over time and among regions.

Open Access This article is distributed under the terms of the Creative Commons Attribution License which permits any use, distribution, and reproduction in any medium, provided the original author(s) and the source are credited.

\section{References}

1. Hoornweg D, Bhada-Tata P (2012) What a waste: a global review of solid waste management. World Bank, Washington, DC

2. OECD (2013) Municipal waste. Environment at a Glance 2013: OECD Indicators. OECD Publishing

3. Liu C, Wu XW (2010) Factors influencing municipal solid waste generation in China: a multiple statistical analysis study. Waste Manag Res 29:371-378. doi:10.1177/0734242X10380114

4. Saeed MO, Hassan MN, Mujeebu MA (2009) Assessment of municipal solid waste generation and recyclable materials potential in Kuala Lumpur, Malaysia. Waste Manag 29:2209-2213. doi:10.1016/j.wasman.2009.02.017

5. Chiemchaisri C, Juanga JP, Visvanathan C (2007) Municipal solid waste management in Thailand and disposal emission inventory. Environ Monit Assess 135:13-20. doi:10.1007/s10661007-9707-1

6. United Nations (undated) Urban and rural areas 2009. http:// www.un.org/en/development/desa/population/publications/urba nization/urban-rural.shtml. Accessed 1 Dec 2014

7. OECD (2003) OECD environmental indicators: development, measurement and use. Reference paper. OECD

8. OECD (2008) OECD key environmental indicators 2008. OECD

9. Brunner PH, Ernst WR (1986) Alternative methods for the analysis of municipal solid waste. Waste Manag Res 4:147-160. doi: $10.1177 / 0734242$ X8600400116

10. Shekdar AV (2009) Sustainable solid waste management: an integrated approach for Asian countries. Waste Manag 29:1438-1448. doi:10.1016/j.wasman.2008.08.025

11. Buenrostro O, Bocco G, Cram S (2001) Classification of sources of municipal solid wastes in developing countries. Resour Conserv Recycl 32:29-41. doi:10.1016/S0921-3449(00)00094-X

12. Rodic L, Scheinberg A, Wilson DC (2010) Comparing solid waste management in the world's cities. Key-note paper at ISWA World Congress 2010, Hamburg. http://www.iswa.org/uploads/ tx_iswaknowledgebase/Rodic.pdf. Accessed 1 Dec 2014

13. European Environment Agency (2013) Managing municipal solid waste-a review of achievements in 32 European countries. European Environment Agency, Copenhagen. http://www.eea. europa.eu/publications/managing-municipal-solid-waste. Accessed 1 Dec 2014

14. Abu Qdais HA, Hamoda MF, Newham J (1997) Analysis of residential solid waste at generation sites. Waste Manag. Res 15:395-406. doi:10.1177/0734242X9701500407

15. Gomez G, Meneses M, Ballinas L, Castells F (2008) Characterization of urban solid waste in Chihuahua, Mexico. Waste Manag 28:2465-2471. doi:10.1016/j.wasman.2007.10.023

16. Gómez G, Meneses M, Ballinas L, Castells F (2009) Seasonal characterization of municipal solid waste (MSW) in the city of Chihuahua, Mexico. Waste Manag 29:2018-2024. doi:10.1016/ j.wasman.2009.02.006

17. Zhang DQ, Tan SK, Gersberg RM (2010) Municipal solid waste management in China: status, problems and challenges. J Environ Manag 91:1623-1633. doi:10.1016/j.jenvman.2010.03.012
18. OECD (2013) Municipal waste. Environment at a Glance 2013: OECD Indicators. OECD

19. Troschinetz AM, Mihelcic JR (2009) Sustainable recycling of municipal solid waste in developing countries. Waste Manag 29:915-923. doi:10.1016/j.wasman.2008.04.016

20. Karak T, Bhagat RM, Bhattacharyya P (2012) Municipal solid waste generation, composition, and management: the world scenario. Crit Rev Environ Sci Technol 42:1509-1630. doi:10. 1080/10643389.2011.569871

21. OECD (undated) Municipal waste, Generation and Treatment. Complete databases available via OECD's iLibrary. http://stats. oecd.org/Index.aspx?DataSetCode=MUNW. Accessed 1 Dec 2014

22. Ministry of the Environment of Japan (undated) Ippan haikibutsu shori jittai chousa kekka (Results of survey on current municipal solid waste management) (in Japanese)

23. United States Environmental Protection Agency (2014) Municipal solid waste generation, recycling, and disposal in the United States: Facts and figures for 2012. United States Environmental Protection Agency, Washington, DC

24. Conference Board of Canada (undated) Municipal Waste Generation. http://www.conferenceboard.ca/hcp/details/environ ment/municipal-waste-generation.aspx. Accessed 1 Dec 2014

25. AIT/UNEP RRC.AP (2010) Municipal waste management report: Status-quo and issues in Southeast and East Asian countries. http://www.environment-health.asia/userfiles/file/Municipal\% 20Waste\%20Report.pdf. Accessed 1 Dec 2014

26. Thein UM (2010) GHG emissions from waste sector of INC of Myanmar. The 8th Workshop on GHG inventories in Asia (WGIA8). Vientiane

27. Asian Development Bank (2013) Solid waste management in Nepal: current status and policy recommendations. Asian Development Bank, Mandaluyong

28. Annepu RK (2012) Sustainable solid waste management in India. Columbia University, New York. http://www.seas.columbia.edu/ earth/wtert/sofos/Sustainable\%20Solid\%20Waste\%20Management \%20in\%20India_Final.pdf. Accessed 1 Dec 2014

29. Enayetullah I, Sinha AHMM, Khan SSA (2005) Urban solid waste management scenario of Bangladesh: problems and prospects. Waste Concern Technical Documentation. http://www.waste concern.org/Publication/Waste\%20Survey_05.pdf. Accessed 1 Dec 2014

30. Phuntsho S, Dulal I, Yangden D, Tenzin UM, Herat S, Shon H, Vigneswaran S (2010) Studying municipal solid waste generation and composition in the urban areas of Bhutan. Waste Manag Res 28:545-551. doi:10.1177/0734242X09343118

31. Masood M, Barlow CY, Wilson DC (2014) An assessment of the current municipal solid waste management system in Lahore, Pakistan. Waste Manag Res 32:834-847. doi:10.1177/ 0734242 X14545373

32. World Bank (1999) What a waste: solid waste management in Asia. http://web.mit.edu/urbanupgrading/urbanenvironment/resour ces/references/pdfs/WhatAWasteAsia.pdf. Accessed 1 Dec 2014

33. Peterson C (2013) Assessment of solid waste management practices and its vulnerability to climate risks in Maldives Tourism Sector. http://tourism.gov.mv/downloads/tap/2014/ Solid_Waste.pdf. Accessed 1 Dec 2014

34. Al-Jarallah R, Aleisa E (2014) A baseline study characterizing the municipal solid waste in the State of Kuwait. Waste Manag 34:952-960. doi:10.1016/j.wasman.2014.02.015

35. United Nations Statistics Division (undated) Environmental indicators: waste. http://unstats.un.org/unsd/environment/muni cipalwaste.htm. Accessed 1 Dec 2014

36. Babayemi JO, Dauda KT (2009) Evaluation of solid waste generation, categories and disposal options in developing countries: a case study of Nigeria. J Appl Sci Environ Manag 13:83-88. doi:10.4314/jasem.v13i3.55370 
37. Eurostat (undated) Municipal waste statistics. http://epp.eurostat. ec.europa.eu/statistics_explained/index.php/Municipal_waste_sta tistics. Accessed 1 Dec 2014

38. Tello Espinoza P, Martínez Arce E, Daza D, Soulier Faure M, Terraza H (2010) Regional evaluation on urban solid waste management in Latin America and the Caribbean: 2010 report. UN-HABITAT

39. Planning Institute of Jamaica (2007) Management of hazardous and solid wastes in Jamaica. http://pioj.gov.jm/portals/0/sustainable development/management_of_wastes.pdf. Accessed 1 Dec 2014

40. Basel Convention, Zoï Environment Network, GRID-Arendal (2012) Biogas and compost. Vital Waste Graphic 3. Basel Convention, Belley

41. Stucki S, Wochele J, Ludwig C, Brandl H, Youcai Z (2003) Waste disposal: what are the impacts? Municipal solid waste management: strategies and technologies for sustainable solutions. Springer, Berlin

42. Khatib IA (2011) Municipal solid waste management in developing countries: future challenges and possible opportunities. Integrated waste management, vol II. InTech, Shanghai

43. Wilson DC, Rodic L, Scheinberg A, Velis CA, Alabaster G (2012) Comparative analysis of solid waste management in 20 cities. Waste Manag Res 30:237-254. doi:10.1177/073424 2X12437569

44. UNDP (2013) Technical notes. Human Development Report 2013. http://hdr.undp.org/sites/default/files/hdr_2013_en_tech notes.pdf. Accessed 1 Dec 2014

45. World Bank (undated) GDP per capita. http://data.worldbank. org/indicator/NY.GDP.PCAP.CD. Accessed 1 Dec 2014

46. World Bank (undated) GNI per capita, Atlas method. http://data. worldbank.org/indicator/NY.GNP.PCAP.CD. Accessed 1 Dec 2014

47. UNDP (undated) Human Development Index. http://hdr.undp. org/en/statistics/hdi. Accessed 1 Dec 2014

48. Chang YM, Liu CC, Hung CY, Hu A, Chen SS (2008) Change in MSW characteristics under recent management strategies in Taiwan. Waste Manag 28:2443-2455. doi:10.1016/j.wasman. 2007.10.014

49. Lu LT, Hsiao TY, Shang NC, Yu YH, Ma HW (2006) MSW management for waste minimization in Taiwan: the last two decades. Waste Manag 26:661-667. doi:10.1016/j.wasman. 2005.10.005

50. Guerrero LA, Maas G, Hogland W (2013) Solid waste management challenges for cities in developing countries. Waste Manag 33:220-232. doi:10.1016/j.wasman.2012.09.008

51. Japan International Cooperation Agency, Pacific Consultants International, Yachiyo Engineering Co., Ltd (2005) The study on the solid waste management in Dhaka City: final report. Japan International Cooperation Agency, Tokyo

52. Hazra T, Goel S (2009) Solid waste management in Kolkata, India: practices and challenges. Waste Manag 29:470-478. doi:10.1016/j.wasman.2008.01.023

53. Dangi MB, Pretz CR, Urynowicz MA, Gerow KG, Reddy JM (2011) Municipal solid waste generation in Kathmandu. Nepal. J Environ Manag 91:240-249. doi:10.1016/j.jenvman.2010.09. 005

54. Jakarta Provincial Government (2012) Solid waste handling management: a case of Jakarta. Review and Planning Workshop on Eco-town, Penang

55. Annepu RK (2012) Sustainable solid waste management in India. Columbia University, United States

56. Muniafu M, Otiato E (2010) Solid waste management in Nairobi, Kenya: a case for emerging economies. J Lang Technol Entrepreneurship Africa 2:342-350

57. Seng B, Kaneko H, Hirayama K, Katayama-Hirayama K (2010) Municipal solid waste management in Phnom Penh, capital city of Cambodia. Waste Manag 29:491-500. doi:10.1177/ 0734242X10380994

58. Batool SA, Chuadhry MN (2009) The impact of municipal solid waste treatment methods on greenhouse gas emissions in Lahore, Pakistan. Waste Manag 29:63-69. doi:10.1016/j.wasman. 2008.01.013

59. Damghani AM, Savarypour G, Zand E, Deihimfard R (2008) Municipal solid waste management in Tehran: current practices, opportunities and challenges. Waste Manag 28:929-934. doi:10. 1016/j.wasman.2007.06.010

60. Zhang D, Keat TS, Gersberg RM (2010) A comparison of municipal solid waste management in Berlin and Singapore. Waste Manag 30:921-933

61. Wang H, Wang C (2012) Municipal solid waste management in Beijing: characteristics and challenges. Waste Manag Res 31:67-72. doi:10.1177/0734242X12468199

62. Aliu IR, Adeyemi OE, Adebayo A (2014) Municipal household solid waste collection strategies in an African megacity: analysis of public private partnership performance in Lagos. Waste Manag 32:67-78. doi:10.1177/0734242X14544354

63. Kawai K, Osako M (2011) Estimation of recyclable waste flows in Hanoi, Vietnam (in Japanese). Environ Sanit Eng Res 25:21-29

64. Yi S, Yoo KY, Hanaki K (2011) Characteristics of MSW and heat energy recovery between residential and commercial areas in Seoul. Waste Manag 31:595-602. doi:10.1016/j.wasman. 2010.09.008

65. World Bank, Ministry of Natural Resources and Environment and Waste-Econ Project (2004) Vietnam environment monitor 2004. World Bank, Hanoi

66. Mateu-Sbert J, Ricci-Cabello I, Villalonga-Olives E, CabezaIrigoyen E (2013) The impact of tourism on municipal solid waste generation: the case of Menorca Island (Spain). Waste Manag 33:2589-2593. doi:10.1016/j.wasman.2013.08.007

67. Saito O (2013) Resource use and waste generation by the tourism industry on the Big Island of Hawaii. J Ind Ecol 17:578-589. doi:10.1111/jiec. 12007

68. Agamuthu P, Fauziah SH (2011) Challenges and issues in moving towards sustainable landfilling in a transitory countryMalaysia. Waste Manag Res 29:13-19. doi:10.1177/0734242 $\mathrm{X} 10383080$

69. UNEP, CalRecovery Inc. (2005) Solid waste management. UNEP

70. UNEP, Secretariat of the basel convention on the control of transboundary movements of hazardous wastes and their disposal (2004) Vital waste graphics. UNEP

71. EU (2008) Directive 2008/98/EC of the European Parliament and of the Council of 19 November 2008 on waste and repealing certain Directives. http://eur-lex.europa.eu/legal-content/EN/ TXT/?uri=CELEX:32008L0098. Accessed 1 Dec 2014

72. McDougall F, White P, Franke M, Hindle P (2001) Integrated solid waste management: a life cycle inventory, 2nd edn. Blackwell Science, Oxford

73. Yeheyis M, Hewage K, Alam MS, Eskicioglu C, Sadiq R (2013) An overview of construction and demolition waste management in Canada: a lifecycle analysis approach to sustainability. Clean Technol Environ Policy 15:81-91. doi:10.1007/s10098-0120481-6

74. Tonjes DJ, Greene KL (2012) A review of national municipal solid waste generation assessments in the USA. Waste Manag Res 30:758-771. doi:10.1177/0734242X12451305

75. Eurostat (2012) Guidance on municipal waste data collection. Eurostat

76. EU (2011) Commission Decision of 18 November 2011 establishing rules and calculation methods for verifying compliance with the targets set in Article 11(2) of Directive 2008/98/EC of the European Parliament and of the Council (notified under 
document C(2011) 8165) (2011/753/EU). http://eur-lex.europa. eu/legal-content/EN/TXT/?qid=1404206037534\&uri=CELEX: 32011D0753. Accessed 1 Dec 2014

77. EU (2000) Commission decision of 3 May 2000 replacing Decision 94/3/EC establishing a list of wastes pursuant to Article 1(a) of Council Directive 75/442/EEC on waste and Council Decision 94/904/EC establishing a list of hazardous waste pursuant to Article 1(4) of Council Directive 91/689/EEC on hazardous waste (notified under document number C (2000) 1147) (2000/532/EC). http://eurlex.europa.eu/LexUriServ/LexUriServ.do?uri=CONSLEG:2000D 0532:20020101:EN:PDF. Accessed 1 Dec 2014

78. Communities European (2005) Waste generated and treated in Europe. Office of Official Publications of the European Communities, Luxembourg

79. Watson D (2013) Municipal waste management in the United Kingdom. European Environment Agency. http://www.eea. europa.eu/publications/managing-municipal-solid-waste/unitedkingdom-municipal-waste-management. Accessed 1 Dec 2014

80. Kjær B (2013) Municipal waste management in the Denmark. European Environment Agency. http://www.eea.europa.eu/pub lications/managing-municipal-solid-waste/denmark-municipalwaste-management. Accessed 1 Dec 2014

81. Fischer C (2013) Municipal waste management in Germany. European Environment Agency. http://www.eea.europa.eu/pub lications/managing-municipal-solid-waste/germany-municipalwaste-management. Accessed 1 Dec 2014

82. Gentil EC (2013) Municipal waste management in France. European Environment Agency. http://www.eea.europa.eu/pub lications/managing-municipal-solid-waste/france-municipal-wastemanagement. Accessed 1 Dec 2014

83. Inter-Organization Programme for the Sound Management of Chemicals (2013) Guidelines for national waste management strategies. UNEP. http://www.unep.org/ietc/Portals/136/Publica tions/Waste\%20Management/UNEP\%20NWMS\%20English.pdf. Accessed 1 Dec 2014

84. Asari M, Sakai S (2011) Consumer perspectives on household hazardous waste management in Japan. J Mater Cycles Waste Manag 13:10-24. doi:10.1007/s10163-010-0313-x

85. Slack RJ, Gronow JR, Voulvoulis N (2009) The management of household hazardous waste in the United Kingdom. J Environ Manag 90:36-42. doi:10.1016/j.jenvman.2008.03.007

86. Miyazaki M, Une H (2005) Infectious waste management in Japan: a revised regulation and a management process in medical institutions. Waste Manag 25:616-621. doi:10.1016/j.was man.2005.01.003

87. Miyazaki M, Imatoh T, Une H (2007) The treatment of infectious waste arising from home health and medical care services: present situation in Japan. Waste Manag 27:130-134. doi:10. 1016/j.wasman.2005.12.018

88. Aliu IR, Adeyemi OE, Adebayo A (2014) Municipal household solid waste collection strategies in an African megacity: analysis of public private partnership performance in Lagos. Waste Manag Res 32:67-78. doi:10.1177/0734242X14544354

89. Lohri CR, Camenzind EJ, Zurbrügg C (2014) Financial sustainability in municipal solid waste management-costs and revenues in Bahir Dar, Ethiopia. Waste Manag 34:542-552. doi:10.1016/j.wasman.2013.10.014

90. Wilson DC, Araba AO, Chinwah K, Cheeseman CR (2009) Building recycling rates through the informal sector. Waste Manag 29:629-635. doi:10.1016/j.wasman.2008.06.016

91. Wilson DC, Velis C, Cheeseman C (2006) Role of informal sector recycling in waste management in developing countries. Habitat Int 30:797-808. doi:10.1016/j.habitatint.2005.09.005

92. Kawai K, Osako M, Matsui S, Dong NT (2012) Identification of junk buyers' contribution to recycling of household waste in
Hanoi, Vietnam, through a physical composition analysis. Waste Manag Res 30:681-688. doi:10.1177/0734242X12444895

93. Rockson GNK, Kemausuor F, Seassey R, Yanful E (2013) Activities of scavengers and itinerant buyers in Greater Accra, Ghana. Habitat Int 39:0148-0155. doi:10.1016/j.habitatint.2012. 11.008

94. Mitchell CL (2008) Altered landscapes, altered livelihoods: the shifting experience of informal waste collecting during Hanoi's urban transition. Geoforum 39:2019-2029. doi:10.1016/j.geo forum.2008.07.006

95. Ezeah C, Fazakerley JA, Roberts CL (2013) Emerging trends in informal sector recycling in developing and transition countries. Waste Manag 33:2509-2519. doi:10.1016/j.wasman.2013.06.020

96. Suttibak S, Nitivattananon V (2008) Assessment of factors influencing the performance of solid waste recycling programs. Resour Recov Conserv 53:45-56. doi:10.1016/j.resconrec.2008. 09.004

97. Velis CA, Wilson DC, Rocca O, Smith SR, Mavropoulos A, Cheeseman CR (2012) An analytical framework and tool ('InteRa') for integrating the informal recycling sector in waste and resource management systems in developing countries. Waste Manag Res 30:43-66. doi:10.1177/0734242X12454934

98. Damanhuri E, Wahyu IM, Ramang R, Padmi T (2009) Evaluation of municipal solid waste flow in the Bandung metropolitan area, Indonesia. J Mater Cycles Waste Manag 11:270-276. doi:10.1007/s10163-009-0241-9

99. Kurniawan TA, Oliveira JPD, Premakumara DGJ, Nagaishi M (2013) City-to-city level cooperation for generating urban cobenefits: the case of technological cooperation in the waste sector between Surabaya (Indonesia) and Kitakyushu (Japan). J Clean Prod 58:43-50. doi:10.1016/j.jclepro.2013.08.002

100. Shimura S, Yokota I, Nitta Y (2001) Research for MSW flow analysis in developing nations. J Mater Cycles Waste Manag 3:48-59. doi:10.1007/s10163-000-0038-3

101. Muttamara S, Visvanathan C, Alwis KU (1994) Solid waste recycling and reuse in Bangkok. Waste Manag Res 12:151-163. doi:10.1177/0734242X9401200205

102. Scheinberg A, Spies S, Simpson MH, Mol APJ (2011) Assessing urban recycling in low- and middle-income countries: building on modernised mixtures. Habitat Int 35:188-198. doi:10.1016/j. habitatint.2010.08.004

103. Kawai K, Huong LTM, Osako M (2012) Accumulation and reliability of data on municipal solid waste management in urban areas of Vietnam. J Jpn Soc Civil Eng Ser G (Environ Res) 68:II_465-II_471

104. UN-HABITAT (2010) State of the world's cities 2010/2011cities for all: bridging the urban divide. UN-HABITAT, London

105. Talyan V, Dahiya RP, Sreekrishnan TR (2008) State of municipal solid waste management in Delhi, the capital of India. Waste Manag 28:1276-1287. doi:10.1016/j.wasman.2007.05.017

106. Department of Environmental Affairs of Republic of South Africa (undated) General waste. State of the environment. http:// soer.deat.gov.za/369.html. Accessed 1 Dec 2014

107. Japan International Cooperation Agency (2005) Supporting capacity development in solid waste management in developing countries - towards improving solid waste management capacity of entire societies. Japan International Cooperation Agency, Tokyo

108. Hiramatsu A, Hara Y, Sekiyama M, Honda R, Chiemchaisri C (2009) Municipal solid waste flow and waste generation characteristics in an urban-rural fringe area in Thailand. Waste Manag Res 27:951-960. doi:10.1177/0734242X09103819

109. Sharholy M, Ahmad K, Mahmood G, Trivedi RC (2008) Municipal solid waste management in Indian cities-a review. Waste Manag 28:459-467. doi:10.1016/j.wasman.2007.02.008 
110. Thao VT (2013) Making a living in rural Vietnam from (im)mobile livelihoods: a case study of women's migration. Popul Space Place 19:87-102. doi:10.1002/psp.1706

111. Chattopadhyay S, Dutta A, Ray S (2009) Municipal solid waste management in Kolkata, India ? A review. Waste Manag 29:1449-1458. doi:10.1016/j.wasman.2008.08.030

112. General Statistics Office of Vietnam, United Nations Population Fund (2006) The 2004 Vietnam migration survey: the quality of life of migrants in Vietnam. Statistical Publishing House, Hanoi

113. UN-HABITAT (2003) The Challenge of Slums - Global Report on Human Settlements 2003. UN-HABITAT, London
114. Kawai K, Huong LTM, Osako M (2012) Progress on collection amount of municipal solid waste in Hanoi, Vietnam (in Japanese). Environ Sanit Eng Res 26:108-111

115. Kawai K (2014) Reliable data collection and compilation of municipal solid waste generation: Challenges and possible improvements at local level in developing countries. 1st 3R International Scientific Conference on Material Cycles and Waste Management. Kyoto 